\title{
Hydration Reactions and Mechanical Strength Developments of Iron- Rich Sulfobelite Eco-cements
}

\author{
Gema Álvarez-Pinazo, ${ }^{\dagger}$ Isabel Santacruz, ${ }^{\dagger}$ Laura León-Reina, ${ }^{\ddagger}$ Miguel A. G. Aranda, ${ }^{\dagger, \S}$ \\ and Angeles G. De la Torre* ${ }^{\dagger}$ \\ ${ }^{\dagger}$ Departamento de Química Inorgánica and ${ }^{\ddagger}$ Servicios Centrales de Apoyo a la Investigación, Universidad de Málaga, Campus \\ Teatinos S/N, 29071 Málaga, Spain \\ ${ }^{\S}$ Consortium for the Exploitation of the Synchrotron Light Laboratory ALBA Synchrotron, Carretera BP 1413, km 3.3, E-08290 \\ Cerdanyola, Barcelona, Spain
}

Supporting Information

ABSTRACT: Belite calcium sulfoaluminate (BCSA) cements are low- $\mathrm{CO}_{2}$ building materials. However, their hydration behavior and its effect on mechanical properties have still to be clarified. Here, we report a full multitechnique study of the hydration behavior up to 120 days of nonactivated and activated BCSA laboratory-prepared clinkers, with $\beta$ - or $\alpha_{\mathrm{H}}$-belite as main phase, respectively. The effects of the amount of gypsum added were also studied. The hydration and crystallization processes are reported and discussed in detail. Finally, shrinkage/expansion data are also given. The optimum amount of gypsum was close to $10 \mathrm{wt} \%$. Our study has demonstrated that $\beta$-belite reacts at a higher pace than $\alpha_{\mathrm{H}^{\prime}}$-belite, irrespective of the gypsum content. The hydration mechanism of belite determines the development of the mechanical strengths. These are much higher for activated BCSA cement, $\sim 65 \mathrm{MPa}$ at 120 days, against $\sim 20 \mathrm{MPa}$ for nonactivated BCSA cement, with the latter having larger amounts of stratlingite.

\section{INTRODUCTION}

Concrete based on ordinary Portland cement (OPC) is the most important building material. Its production is regarded as the third largest source of $\mathrm{CO}_{2}$ emission, after combustion of fossil fuels and deforestation. $\mathrm{CO}_{2}$ emissions emanating from cement kilns are associated with burning of carbon-based fuels $(\sim 40 \%)$ and decarbonation of limestone $(\sim 60 \%){ }^{1}$ It is estimated that the global cement industry produces around 1.4 billion metric tons of $\mathrm{CO}_{2}$ per year, or about $6 \%$ of worldwide man-made $\mathrm{CO}_{2}$ emissions. ${ }^{2}$ There are several possibilities to reduce the environmental impact of cement production, such as blending Portland clinker/cement with, for instance, fly ashes or slags, using alternative fuels in the cement kiln, or developing low-carbon binders, such as pozzolandbased, sulfate-based, or low-calcite-demanding cements. ${ }^{3}$ The latter binders are based on belite $\left(\mathrm{C}_{2} \mathrm{~S}\right)^{4}$ or ye'elimite $\left(\mathrm{C}_{4} \mathrm{~A}_{3} \overline{\mathrm{S}}\right) .^{5-7}$ Ye'elimite-rich cements, also called calcium sulfoaluminate (CSA) cements, are mainly manufactured in China and their production, when compared to that of OPC, may reduce $\mathrm{CO}_{2}$ emissions up to $40 \%$. However, CSA cements are commonly used for niche applications ${ }^{8}$ due to their high prices, associated with the high demand for expensive bauxite. Belite calcium sulfoaluminate ${ }^{6}$ (BCSA) or sulfobelite cements have belite as the main phase, with ye'elimite as a second component, and require much lower amounts of bauxite compared to CSA cements. The $\mathrm{CO}_{2}$ footprint of sulfobelite cements is about $30 \%$ lower than that of OPC. Compared to low-cost (and low-performance) belite-rich cements ${ }^{4}$ and highcost (and high-performance) CSA cements, sulfobelite cements are expected to show in-between behavior. The most common composition of BCSA clinkers includes $\beta-\mathrm{C}_{2} \mathrm{~S}, \mathrm{C}_{4} \mathrm{~A}_{3} \overline{\mathrm{S}}$, and $\mathrm{C}_{4} \mathrm{AF} ;{ }^{6,9,10}$ being iron-rich sulfobelite materials, they are hereafter named as BCSAF. They are produced at $\sim 1300{ }^{\circ} \mathrm{C}$ and show rapid hardening, good durability, self-stressing ability, and volume stability, depending on the amount of added gypsum; furthermore, they can be easily ground due to their high porosity, caused by lower clinkering temperature. ${ }^{6}$ Recently, a new class of BCSAF cements has been patented by Lafarge, 9,11 to which stabilization of high-temperature belite polymorphs ( $\alpha$-forms) is given (for instance with borax) together with high early mechanical strength. However, the hydration chemistry and durability of mortars derived from these eco-cements must be profoundly studied. Ye'elimite and calcium sulfate (in the form of anhydrite or gypsum) govern the initial reactions and give early strengths. The hydration of ye'elimite in the presence of calcium sulfate provokes the precipitation of crystalline ettringite $\left(\mathrm{C}_{6} \mathrm{AS}_{3} \mathrm{H}_{32}\right)$, also called $\mathrm{AFt}$, and amorphous aluminum hydroxide according to the following reaction:

$$
\mathrm{C}_{4} \mathrm{~A}_{3} \overline{\mathrm{S}}+2 \mathrm{C} \overline{\mathrm{S}} \mathrm{H}_{2}+34 \mathrm{H} \rightarrow \mathrm{C}_{6} \mathrm{~A}_{3} \mathrm{H}_{32}+2 \mathrm{AH}_{3}
$$

Phases coming from hydration of brownmillerite and gypsum (see reaction 2) are identified as $\mathrm{AFt}, \mathrm{CH}$, and an iron-rich amorphous phase with a stoichiometry close to $\mathrm{FH}_{3}{ }^{12}$ which slightly contributes to later strength development.

$$
\mathrm{C}_{4} \mathrm{AF}+3 \mathrm{C} \overline{\mathrm{S}} \mathrm{H}_{2}+30 \mathrm{H} \rightarrow \mathrm{C}_{6} \mathrm{AS}_{3} \mathrm{H}_{32}+\mathrm{FH}_{3}+\mathrm{CH}
$$

Received: July 31, 2013

Revised: October 18, 2013

Accepted: October 28, 2013

Published: October 28, 2013 
If there is a lack/depletion of sulfates, then $\mathrm{C}_{4} \mathrm{~A}_{3} \overline{\mathrm{S}}$ and $\mathrm{C}_{4} \mathrm{AF}$ may hydrate to give a different type of hydrated phases called AFm (which are explained below) instead of AFt. However, the hydration process involving iron-containing phases may be more complex, as the formation of solid solutions between Feand $\mathrm{Al}$-containing hydrates could stabilize mixed solids, such as $\mathrm{Fe}_{\mathrm{AFt}}{ }^{13}$ and $\mathrm{Fe}-\mathrm{AFm}$. $^{14}$

On the other hand, belite hydration kinetics seems to depend on polymorphism. Thus, $\alpha$-forms of belite are considered more reactive than $\beta-C_{2} S .{ }^{4,15}$ Nevertheless, it should be noted that the presence of sulfate in the belite structure may enhance its reactivity due to the enlargement of its specific surface and/or occurrence of crystal distortions. ${ }^{16,17}$ The hydration of belite was also studied, and $\mathrm{C}-\mathrm{S}-\mathrm{H}$ by some authors ${ }^{18}$ and stratlingite by others ${ }^{19}$ were identified as hydration products. According to the distinct hydrates, two chemical reactions, 3 and 4 (see below), are proposed in the scientific literature. Reaction 3 corresponds to the formation of (i) the so-called $\mathrm{C}-\mathrm{S}-\mathrm{H}$ gel, an amorphous hydrate, ${ }^{18}$ and (ii) crystalline portlandite. Reaction 4 shows the formation of an AFm-type phase called stratlingite. ${ }^{19}$

$$
\begin{aligned}
& \mathrm{C}_{2} \mathrm{~S}+(2-x+y) \mathrm{H} \rightarrow \mathrm{C}_{x} \mathrm{SH}_{y}+(2-x) \mathrm{CH} \\
& \mathrm{C}_{2} \mathrm{~S}+\mathrm{AH}_{3}+5 \mathrm{H} \rightarrow \mathrm{C}_{2} \mathrm{ASH}_{8}
\end{aligned}
$$

AFm-type compounds have a layer structure with the general formula $\left[\mathrm{Ca}_{2} \mathrm{Al}(\mathrm{OH})_{6}\right] \mathrm{X} \cdot x \mathrm{H}_{2} \mathrm{O}$, where $\mathrm{X}$ denotes one formula unit of a singly charged anion, $\left[\mathrm{SiAlO}_{2}(\mathrm{OH})_{4}\right]^{-}$in the case of stratlingite, or half a formula unit of a doubly charged anion placed in the interlayer space jointly with water molecules. In the particular case of stratlingite, the singly charged anion forms a double tetrahedral layer with the existence of $\sim 45 \%$ vacancy within it. ${ }^{20}$ Moreover, iron-bearing stratlingite may also be formed by partial substitution of aluminum in the octahedral layer. ${ }^{21}$ Moreover, as $\mathrm{pH}$ and calcium concentration increase, the formation of katoite or siliceous hydrogarnet may occur by reaction 5 , in which ferrite phase takes place:

$$
\begin{aligned}
& \mathrm{C}_{2} \mathrm{~S}+x \mathrm{C}_{4} \mathrm{AF}+10 x \mathrm{H} \\
& \quad \rightarrow \mathrm{C}_{3} \mathrm{~A}_{1-x} \mathrm{~F}_{x} \mathrm{SH}_{4}+(4 x-1) \mathrm{CH}+(2 x-1) \mathrm{AH}_{3}
\end{aligned}
$$

It has also been stated that katoite may be formed by the reaction between belite and stratlingite. ${ }^{21}$

The mechanism of hydration of these cements needs to be worked out in depth to have predictable long-term performances for the related concretes. Both the kinetics of the hydration reaction and the nature of hydration products need to be understood to better formulate cements based on BCSAF clinkers. In addition, the stability of the hydration products under various conditions must be gathered in order to be able to make realistic predictions of concrete durability. According to thermodynamic studies, stratlingite cannot coexist stably with $\mathrm{CH}$. On the other hand, low-calcium $\mathrm{C}-\mathrm{S}-\mathrm{H}$ gels can coexist with katoite and stratlingite phases, and even aluminum hydroxide. $^{22}$ Laboratory X-ray powder diffraction (LXRPD) analysis combined with Rietveld methodology is an ideal tool to study both anhydrous cementitious materials ${ }^{23}$ and the corresponding hydration processes. ${ }^{10,17,24}$

The aims of this work are (i) to study the hydration behavior of two laboratory-prepared BCSAF cements $\left(\beta-\mathrm{C}_{2} \mathrm{~S}\right.$ and $\alpha^{\prime}{ }_{\mathrm{H}^{-}}$ $\mathrm{C}_{2} \mathrm{~S}$ ) having different gypsum contents and (ii) to find correlations with their mechanical properties.

\section{EXPERIMENTAL SECTION}

Materials. Preparation of Anhydrous Cements. Two BCSAF clinkers [B0 (undoped) and B2 (doped with 2 wt \% $\mathrm{B}_{2} \mathrm{O}_{3}$, added as borax)] were prepared in our laboratory as previously reported. ${ }^{25}$ The phase compositions of the clinkers were close to $50 \mathrm{wt} \% \mathrm{C}_{2} \mathrm{~S}, 30$ wt $\% \mathrm{C}_{4} \mathrm{~A}_{3} \overline{\mathrm{S}}$, and 20 wt $\% \mathrm{C}_{4} \mathrm{AF}$. Both B0 clinker (density $3.14 \mathrm{~g} / \mathrm{cm}^{3}$, Blaine surface area 4260 $\mathrm{cm}^{2} / \mathrm{g}$ ) and B2 clinker (density $3.04 \mathrm{~g} / \mathrm{cm}^{3}$, Blaine surface area $4380 \mathrm{~cm}^{2} / \mathrm{g}$ ) were mixed with three different amounts of gypsum $(5,10$, and $15 \mathrm{wt} \%)$ in an automatic mixer during 15 min, hereafter labeled as $\mathrm{CgB} x$, where $g=5,10$, or 15 and $x=0$ or $2\left(\mathrm{~B}_{2} \mathrm{O}_{3}\right.$ content $)$. The gypsum used was commercial micronized natural gypsum marketed by Belith S.P.R.L. (Belgium). Column $t_{0}$ in Tables 1 and 2 gives the Rietveld quantitative phase analysis (RQPA), including amorphous and crystalline nonquantified (ACn) phases and free water (FW) contents for all the cements. ACn content computes not only an amorphous fraction but any not-computed crystalline phase and any misfit problem (for instance, the lack of adequate structural description for a given phase). Furthermore, FW content stands for the water nonchemically bonded. Table S1 (Supporting Information) shows elemental analysis of both clinkers and gypsum determined by X-ray fluorescence (XRF) through a Magic X spectrometer (PANalytical, Almelo, The Netherlands).

Two commercial cements, OPC (CEM-I 52.5R) marketed by Italcementi Group (FyM, Málaga, Spain) and CSA (sold by BELITH S.P.R.L., Belgium, and composed by a Chinese industrial clinker), were used to complete the study for the sake of comparison.

Preparation of Cement Pastes. All cement pastes were prepared with distilled water at a w/c ratio of 0.55 . The pastes were mixed in an agate mortar and placed over a methacrylate sample holder covered with plastic wrap and stored at $20 \pm 1$ ${ }^{\circ} \mathrm{C}$ and $99 \%$ relative humidity $(\mathrm{RH})$ in a humidity chamber for $3,7,28$, and 120 days. At the end of each aging time, pastes were divided into two fractions to perform further characterization, as detailed below.

Procedure for Stopping the Hydration of Pastes. One fraction of the pastes was milled to fine powder in an agate mortar before the hydration was stopped. The experimental procedure to stop the hydration consisted of filtration (through a $90 \mathrm{~mm}$ diameter Whatman filter having a pore size of $2.5 \mu \mathrm{m}$ and a Teflon support) with acetone twice and finally with ether. This procedure is gentle enough to preserve the entire fraction of bound water in the crystalline lattice of hydrated phases. ${ }^{26}$ The samples treated with acetone/ether were stored in sealed plastic containers within a desiccator with silica gel and $\mathrm{KOH}$ to avoid further hydration and carbonation from the environment. ${ }^{21,27}$

Analytical Techniques. Laboratory X-ray Powder Diffraction Data Analysis. LXRPD studies were performed on the cured cement pastes after hydration was stopped. In order to evaluate the ACn content, an external standard approach was employed. $^{28-30}$ LXRPD patterns of the samples were analyzed by the Rietveld method as implemented in the GSAS software package $^{31}$ through the use of a pseudo-Voigt peak shape function $^{32}$ including the asymmetry correction. ${ }^{33}$ The refined overall parameters were phase scale factors, background coefficients, unit cell parameters, zero-shift error, peak shape parameters, and preferred orientation coefficient, if needed. March-Dollase ellipsoidal preferred orientation correction 
Table 1. RQPA Results for Phase Concentration in CgB0 Pastes Cured at Different Hydration Times ${ }^{a}$

\begin{tabular}{|c|c|c|c|c|c|c|c|c|c|c|c|c|c|c|c|}
\hline & \multicolumn{5}{|c|}{ C5B0 } & \multicolumn{5}{|c|}{ С10B0 } & \multicolumn{5}{|c|}{ C15B0 } \\
\hline & $t_{0}$ & $3 \mathrm{~d}$ & $7 \mathrm{~d}$ & $28 \mathrm{~d}$ & $120 \mathrm{~d}$ & $t_{0}$ & $3 \mathrm{~d}$ & $7 \mathrm{~d}$ & $28 \mathrm{~d}$ & $120 \mathrm{~d}$ & $t_{0}$ & $3 d$ & $7 d$ & $28 \mathrm{~d}$ & $120 \mathrm{~d}$ \\
\hline$\beta-\mathrm{C}_{2} \mathrm{~S}$ & 22.2 & 19.7 & 16.5 & 11.4 & 7.8 & 21.0 & 21.6 & 18.7 & 11.2 & 7.3 & 19.9 & 21.6 & 20.6 & 10.4 & 5.0 \\
\hline $\mathrm{o}-\mathrm{C}_{4} \mathrm{~A}_{3} \overline{\mathrm{S}}$ & 12.8 & 0.2 & & & & 12.1 & 0.2 & & & & 11.5 & & & & \\
\hline $\mathrm{C}_{4} \mathrm{AF}$ & 6.8 & 1.0 & & & & 6.5 & 2.4 & 0.9 & & & 6.1 & 4.3 & 2.2 & 0.4 & \\
\hline $\mathrm{CT}$ & 0.6 & 0.4 & 0.3 & & & 0.6 & 0.5 & 0.3 & 0.1 & & 1.8 & 0.2 & 0.3 & & \\
\hline $\mathrm{C}_{2} \mathrm{AS}$ & 2.0 & 2.7 & 2.7 & 2.3 & 2.5 & 1.9 & 2.6 & 2.5 & 2.3 & 2.4 & 1.0 & 2.3 & 2.3 & 2.2 & 2.1 \\
\hline$\gamma-\mathrm{C}_{2} \mathrm{~S}$ & 1.2 & 1.8 & 1.8 & 1.5 & 1.6 & 1.1 & 1.5 & 1.5 & 1.4 & 1.4 & 0.6 & 1.0 & 1.1 & 1.1 & 1.1 \\
\hline $\mathrm{C} \overline{\mathrm{S}} \mathrm{H}_{2}$ & 3.2 & & & & & 6.5 & & & & & 9.7 & & & & \\
\hline $\mathrm{AFt}$ & & 7.8 & 5.2 & 4.8 & 5.7 & & 14.3 & 12.6 & 12.3 & 13.5 & & 22.6 & 19.2 & 21.2 & 21.2 \\
\hline stratlingite & & 20.4 & 28.8 & 29.7 & 29.0 & & 11.1 & 20.3 & 23.7 & 24.6 & & & 7.5 & 15.8 & 13.5 \\
\hline AFm & & 0.8 & 0.9 & 1.0 & 0.9 & & 0.4 & 0.2 & 0.4 & 0.2 & & & & 0.3 & \\
\hline katoite & & & 1.9 & 5.6 & 7.5 & & & 1.0 & 6.6 & 7.0 & & & 0.8 & 9.7 & 10.6 \\
\hline gibbsite & & & & & & & & & & & & 0.4 & 0.4 & & \\
\hline Cㅡㅡ (vaterite) & & & & & & & & & & & & & & & 1.6 \\
\hline Cㅡ (calcite) & & & & & 0.4 & & & & 0.4 & 0.7 & & & & 0.1 & 2.5 \\
\hline $\mathrm{ACn}$ & 15.6 & 33.2 & 30.9 & 34.1 & 34.8 & 14.8 & 32.6 & 30.4 & 32.8 & 34.4 & 14.0 & 33.6 & 32.6 & 30.8 & 34.0 \\
\hline FW & 35.5 & 12.3 & 11.3 & 9.5 & 9.9 & 35.5 & 13.0 & 11.7 & 9.0 & 8.4 & 35.5 & 13.8 & 13.0 & 7.9 & 8.4 \\
\hline
\end{tabular}

Table 2. RQPA Results for Phase Concentrations in CgB2 Pastes at Different Hydration Times ${ }^{a}$

\begin{tabular}{|c|c|c|c|c|c|c|c|c|c|c|c|c|c|c|c|}
\hline & \multicolumn{5}{|c|}{$\mathrm{C} 5 \mathrm{~B} 2$} & \multicolumn{5}{|c|}{ C10B2 } & \multicolumn{5}{|c|}{$\mathrm{C} 15 \mathrm{~B} 2$} \\
\hline & $t_{0}$ & $3 \mathrm{~d}$ & $7 \mathrm{~d}$ & $28 \mathrm{~d}$ & $120 \mathrm{~d}$ & $t_{0}$ & $3 \mathrm{~d}$ & $7 \mathrm{~d}$ & $28 \mathrm{~d}$ & $120 \mathrm{~d}$ & $t_{0}$ & $3 \mathrm{~d}$ & $7 \mathrm{~d}$ & $28 \mathrm{~d}$ & $120 \mathrm{~d}$ \\
\hline$\alpha_{\mathrm{H}^{-}}^{\prime} \mathrm{C}_{2} \mathrm{~S}$ & 24.6 & 25.3 & 24.9 & 16.7 & 9.6 & 23.3 & 25.2 & 24.2 & 17.0 & 9.0 & 22.0 & 23.0 & 23.9 & 20.5 & 12.8 \\
\hline $\mathrm{c}-\mathrm{C}_{4} \mathrm{~A}_{3} \overline{\mathrm{S}}$ & 13.6 & 1.4 & 1.1 & 0.3 & & 12.8 & 0.9 & 0.8 & & & 12.1 & 0.2 & 0.3 & & \\
\hline $\mathrm{C}_{4} \mathrm{AF}$ & 4.4 & 3.5 & 3.1 & & & 4.2 & 4.0 & 3.8 & & & 3.9 & 4.0 & 3.7 & 3.2 & 0.3 \\
\hline $\mathrm{CT}$ & 0.9 & 0.8 & 0.9 & 0.3 & & 0.9 & 0.8 & 0.8 & 0.2 & & 0.8 & 0.6 & 0.8 & 0.6 & \\
\hline $\mathrm{C}_{2} \mathrm{AS}$ & 1.0 & 0.9 & 1.2 & 1.1 & 0.9 & 1.0 & 1.0 & 0.8 & 0.9 & 0.8 & 1.0 & 0.9 & 0.9 & 0.9 & 0.9 \\
\hline $\mathrm{C} \overline{\mathrm{S}} \mathrm{H}_{2}$ & 3.2 & & & & & 6.5 & & & & & 9.7 & & & & \\
\hline $\mathrm{AFt}$ & & 10.6 & 11.6 & 10.1 & 12.6 & & 17.5 & 19.3 & 15.9 & 18.6 & & 22.6 & 25.0 & 22.6 & 23.5 \\
\hline stratlingite & & 3.7 & 7.5 & 12.4 & 14.5 & & 1.2 & 2.7 & 6.1 & 8.6 & & 0.5 & 0.4 & 0.8 & 4.7 \\
\hline $\mathrm{AFm}$ & & 0.2 & 0.2 & & & & & & & & & & & & \\
\hline katoite & & & & 7.9 & 8.6 & & 0.4 & 0.3 & 4.8 & 9.1 & & 0.4 & 0.3 & 0.5 & 4.2 \\
\hline gibbsite & & 0.2 & 0.4 & 0.4 & 0.4 & & 0.4 & 0.4 & 0.4 & 0.3 & & 0.5 & 0.6 & 0.5 & 0.4 \\
\hline Cㅡ (vaterite) & & & & 0.4 & 0.4 & & & & 0.9 & 0.3 & & & & 1.1 & 0.3 \\
\hline Cㅡ (calcite) & & & & & 1.1 & & & & & 0.4 & & & & & 0.6 \\
\hline $\mathrm{ACn}$ & 16.7 & 36.0 & 31.7 & 40.0 & 43.1 & 15.8 & 32.9 & 30.5 & 42.7 & 45.1 & 14.9 & 33.0 & 30.9 & 36.9 & 43.6 \\
\hline FW & 35.5 & 17.1 & 17.4 & 10.6 & 9.0 & 35.5 & 15.7 & 16.6 & 11.1 & 7.7 & 35.5 & 14.3 & 13.1 & 12.3 & 8.9 \\
\hline
\end{tabular}

${ }^{a}$ Percent by mass, including ACn calculated with G-method and free water.

algorithm was employed. ${ }^{34}$ The G-factor approach was used to obtain a full mineralogical phase assemblage which includes amorphous contents. This approach quantifies not only amorphous/subcooled phases but also any misfitting problems of the analyzed crystalline phases and the nonincluded crystalline phases $(\mathrm{ACn}){ }^{35}$ The absolute weight fractions for all crystalline phases were derived via the G-factor approach from their refined scale factors, and ACn contents were obtained from the difference of the total crystalline phases to 100 , as the mass attenuation coefficients of the samples were known.

The structural descriptions used for all the phases were those given in ref 35 except for $\alpha^{\prime}{ }_{\mathrm{H}^{-}} \mathrm{C}_{2} \mathrm{~S}^{36}$ and orthorhombic $\mathrm{C}_{4} \mathrm{~A}_{3} \mathrm{~S}^{37}{ }^{37}$ for which two revised crystal structure descriptions have been used. The crystal structure description for $\mathrm{C}_{4} \mathrm{AF}$ used has $\mathrm{Al} / \mathrm{Fe}$ $=1.0$ with $50 \%$ of $\mathrm{Fe}$ in $\left(\begin{array}{lll}0 & 0 & 0\end{array}\right)$ site and $50 \%$ of $\mathrm{Fe}$ in $(0.9283$ $1 / 40.9533)$, which fits better with our data.

Thermal Analysis. Two experiments were performed:

(i) Loss on ignition (LoI): a fraction of all pastes (without stopping hydration) was measured for a given time of hydration immediately after removal from the humidity chamber, to avoid lost of free water and further hydration. The thermal treatment was heating the samples up to $800{ }^{\circ} \mathrm{C}$ at a heating rate of 10 ${ }^{\circ} \mathrm{C} / \mathrm{min}$ and holding that temperature for $1.5 \mathrm{~h}$.

(ii) Differential thermal analysis (DTA) and thermogravimetric analysis (TGA): the stopped pastes for a given age were ground and DTA-TGA measurements were performed in a SDT-Q600 analyzer from TA Instruments (New Castle, DE). The temperature was varied from room temperature to 1000 ${ }^{\circ} \mathrm{C}$ at a heating rate of $10{ }^{\circ} \mathrm{C} / \mathrm{min}$. Measurements were carried out in open platinum crucibles under nitrogen flow. The weight loss from room temperature to $600{ }^{\circ} \mathrm{C}$ was assumed to be chemically bonded water, and that from 600 to $1000{ }^{\circ} \mathrm{C}$ was considered as $\mathrm{CO}_{2}$. Table S2 (Supporting Information) lists all these data, as well as the theoretical total weight loss (calculated with both w/c ratio and gypsum content taken into account).

Compressive Strength and Dimensional Stability Tests. Standard mortars were prepared with a cement/sand/water ratio of $1 / 3 / 0.55$ in order to study the mechanical properties. Mortars were mixed according to EN196-1. Compressive 
Table 3. Hydration Degree ${ }^{a}$ of $\mathrm{C}_{2} \mathrm{~S}, \mathrm{C}_{4} \mathrm{~A}_{3} \overline{\mathrm{S}}$, and $\mathrm{C}_{4} \mathrm{AF}$ for $\mathrm{CgB0}$ and $\mathrm{CgB} 2$ Pastes

\begin{tabular}{|c|c|c|c|c|c|c|c|c|c|c|c|c|}
\hline & \multicolumn{4}{|c|}{ С5B0 } & \multicolumn{4}{|c|}{ C10B0 } & \multicolumn{4}{|c|}{ C15B0 } \\
\hline & $3 \mathrm{~d}$ & $7 \mathrm{~d}$ & $28 \mathrm{~d}$ & $120 \mathrm{~d}$ & $3 \mathrm{~d}$ & $7 \mathrm{~d}$ & $28 \mathrm{~d}$ & $120 \mathrm{~d}$ & $3 \mathrm{~d}$ & $7 \mathrm{~d}$ & $28 \mathrm{~d}$ & $120 \mathrm{~d}$ \\
\hline$\beta-\mathrm{C}_{2} \mathrm{~S}$ & 12 & 26 & 49 & 65 & 0 & 11 & 47 & 65 & 0 & 0 & 48 & 75 \\
\hline o- $\mathrm{C}_{4} \mathrm{~A}_{3} \overline{\mathrm{S}}$ & 99 & 100 & 100 & 100 & 99 & 100 & 100 & 100 & 100 & 100 & 100 & 100 \\
\hline \multirow[t]{3}{*}{$\mathrm{C}_{4} \mathrm{AF}$} & 86 & 100 & 100 & 100 & 64 & 86 & 100 & 100 & 29 & 64 & 94 & 100 \\
\hline & \multicolumn{4}{|c|}{ C5B2 } & \multicolumn{5}{|c|}{ C10B2 } & \multicolumn{3}{|c|}{$\mathrm{C} 15 \mathrm{~B} 2$} \\
\hline & $3 \mathrm{~d}$ & $7 \mathrm{~d}$ & $28 \mathrm{~d}$ & $120 \mathrm{~d}$ & $3 \mathrm{~d}$ & $7 \mathrm{~d}$ & $28 \mathrm{~d}$ & $120 \mathrm{~d}$ & $3 \mathrm{~d}$ & $7 \mathrm{~d}$ & $28 \mathrm{~d}$ & $120 \mathrm{~d}$ \\
\hline$\alpha_{\mathrm{H}^{-}}^{\prime} \mathrm{C}_{2} \mathrm{~S}$ & 0 & 0 & 32 & 61 & 0 & 0 & 27 & 62 & 0 & 0 & 7 & 42 \\
\hline $\mathrm{c}-\mathrm{C}_{4} \mathrm{~A}_{3} \overline{\mathrm{S}}$ & 90 & 92 & 98 & 100 & 93 & 94 & 100 & 100 & 99 & 98 & 100 & 100 \\
\hline $\mathrm{C}_{4} \mathrm{AF}$ & 21 & 29 & 100 & 100 & 5 & 10 & 100 & 100 & 0 & 5 & 17 & 93 \\
\hline
\end{tabular}

strengths were measured on cubic samples of $30 \times 30 \times 30$ $\mathrm{mm}$. The samples were cast on a jolting table (model UTCM0012, 3R, Montauban, France) with a total of 120 jolts. For better homogeneity, molds were half cast and jolted for 60 times; then they were fully cast and another 60 jolts were applied. Casts were cured at $20 \pm 1{ }^{\circ} \mathrm{C}$ and $99 \% \mathrm{RH}$ for $24 \mathrm{~h}$; then samples were demolded and cured within a water bath at $20 \pm 1{ }^{\circ} \mathrm{C}$ until testing. The compressive strengths of mortars were measured at $3,7,28$, and 120 days, and the reported value is the average of three measurements under the compression machine (Model Autotest 200/10 W, Ibertest, Madrid, Spain). The measured compressive strength values were corrected by a factor of 1.78 in order to obtain values comparable to those determined by use of standard prisms $(40 \times 40 \times 160$ $\mathrm{mm})$.This factor is obtained by dividing the compression area of the machine $\left(1600 \mathrm{~mm}^{2}\right)$ between the specimen area $(900$ $\mathrm{mm}^{2}$ ). For the sake of comparison, two equivalent mortar cubes prepared with OPC and CSA at a cement/sand/water ratio of $1 / 3 / 0.50$ were also submitted to mechanical testing.

The dimensional stability of all the mortars, BCSAF, OPC, and CSA, was measured with standard prismatic samples $(40 \times$ $40 \times 160 \mathrm{~mm})$ by applying the equation $\Delta L(\%)=\left[\left(L_{\mathrm{f}}-L_{0}\right) /\right.$ $\left.L_{0}\right] \times 100$, where $L_{\mathrm{f}}$ is the measured length at a given time and $L_{0}$ is the initial length. The latter was taken just after demolding and prior to immersion in water. The preparation and curing procedure for these specimens was the same as detailed before.

\section{RESULTS AND DISCUSSION}

The cured pastes, after hydration was stopped, were characterized by LXRPD and Rietveld methodology at 3, 7, 28, and 120 days. Tables 1 and 2 show RQPA obtained for all the cement pastes at different ages, including $\mathrm{ACn}$ and FW contents. The latter was determined by the difference between the added water and the combined water determined by differential thermo-thermogravimetric analysis (DTA-TGA) (Table S2, Supporting Information.

Table 3 shows the hydration degree $(\alpha)$ of the three main starting crystalline phases for $\mathrm{CgB0}$ and $\mathrm{CgB} 2$ pastes as a function of curing time and amount of gypsum added, calculated according to the following expression and using the data from Tables 1 and 2:

$$
\alpha=\frac{w_{\text {phase- } n}^{t_{0}}-w_{\text {phase- } n}^{t}}{w_{\text {phase- } n}^{t_{0}}} \times 100
$$

where $w_{\text {phase- } n}^{t_{0}}$ and $w_{\text {phase- } n}^{t}$ stand for the weight percentages at the beginning $\left(t_{0}\right)$ of the hydration and at a given time $(t)$, respectively.
The main differences in terms of phase assemblage between anhydrous BCSAF clinkers were the stabilization of $\alpha^{\prime}{ }_{\mathrm{H}^{-}} \mathrm{C}_{2} \mathrm{~S}$ and the cubic symmetry of $\mathrm{C}_{4} \mathrm{~A}_{3} \overline{\mathrm{S}}$ in $\mathrm{B} 2$, against the occurrence of the $\beta$-form of belite and of orthorhombic ye'elimite for B0.

The influence of the activation of clinkers can be followed by examining the data reported in Tables $1-3$. Several results can be drawn. First, gypsum is consumed very quickly in all the samples; hence it is not detected after 3 days of hydration. Second, ye'elimite also reacts quite fast although at a different pace for B0 and B2 (Table 3). Orthorhombic ye'elimite is completely hydrated after 3 days of hydration in $\mathrm{CgB0}$, while cubic ye'elimite in $\mathrm{CgB} 2$ reacts at a slightly slower pace when gypsum content and age of hydration are the same. This effect was previously observed. ${ }^{38}$ Ye'elimite hydration/reaction kinetics show a small dependence on the amount of added gypsum, as there is a slight increase in hydration rate with increasing gypsum content. Third, the ferrite phase hydration rate for $\mathrm{CgB} 2$ is slightly slower than that for $\mathrm{CgB0}$ : $1.0 \mathrm{wt} \%$ $\mathrm{C}_{4} \mathrm{AF}$ was quantified for $\mathrm{C} 5 \mathrm{~B} 0$ after 3 days, whereas $3.5 \mathrm{wt} \%$ remained in $\mathrm{C} 5 \mathrm{~B} 2$ at the same time. Although that difference is small, it indicates a certain tendency. Moreover, the hydration of the ferrite phase was strongly retarded with increasing gypsum content, in agreement with previous studies. ${ }^{21}$ Even after 120 days, $\mathrm{C}_{4} \mathrm{AF}$ remained in a small amount in C15B2, whereas it was completely hydrated after 28 days in C5B2.

The hydration of dicalcium silicate showed the same behavior as that of ferrite phase, as the increase in added gypsum has slightly retarded its hydration pace, apart from the polymorphism. However, the increase in gypsum content differently affected the final reaction degree of both polymorphs. On the one hand, $\beta-\mathrm{C}_{2} \mathrm{~S}$ reactivity was enhanced as a result of $15 \mathrm{wt} \%$ gypsum addition ( $\alpha$ from $65 \%$ to $75 \%$ ) whereas $\alpha^{\prime}{ }_{\mathrm{H}^{-}} \mathrm{C}_{2} \mathrm{~S}$ was hydrated at a lower pace by increasing sulfate content ( $\alpha$ from $62 \%$ to $42 \%$ ). Furthermore, the most surprising result achieved from Table 3 was that $\beta$-belite in B0 reacts at a higher pace than $\alpha^{\prime}{ }_{\mathrm{H}}$-belite in $\mathrm{B} 2$, for a fixed gypsum content and hydration time. This latter result contradicts the findings of previous studies. ${ }^{4,39}$ However, a similar behavior was reported $^{17}$ for $\beta-\mathrm{C}_{2} \mathrm{~S}$ contained in aluminum-rich BCSA cements, which react faster at early ages, about $34 \mathrm{~h}$, when compared to a belite-rich Portland cement. ${ }^{40}$ Thus, the reactivity of $\beta-\mathrm{C}_{2} \mathrm{~S}$ seems to be enhanced when an oversaturation of aluminate ions at early hours of hydration occurs in pore solution to yield stratlingite. ${ }^{17,38,41}$

Concerning the hydration products, it was observed that the main crystalline compounds were ettringite, stratlingite, and katoite. Figure 1 shows, as a representative example, a selected 
range of Rietveld plots for two samples, C5B0 and C5B2, hydrated for 120 days.

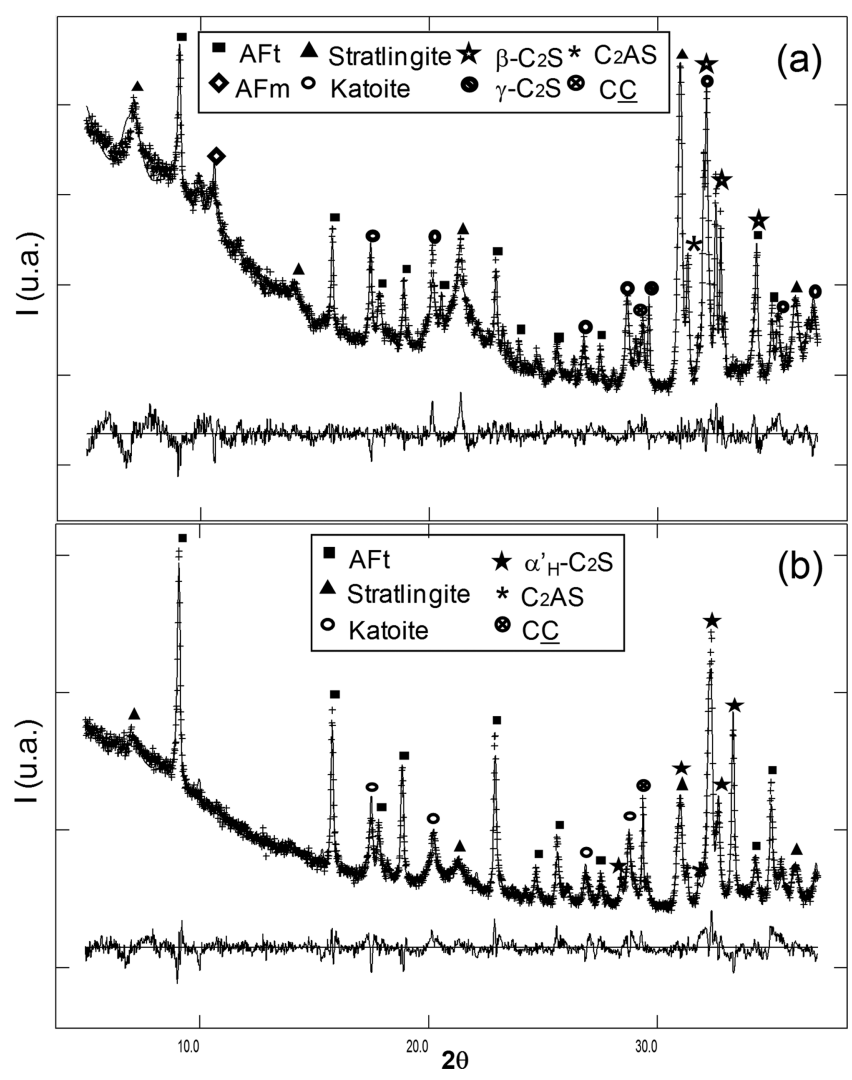

Figure 1. Selected range of Rietveld plots for two pastes, (a) C5B0 and (b) C5B2, cured for 120 days. Cross symbols and line stand for observed and calculated powder patterns, respectively, and the bottom line is the difference curve.

The main peaks for each phase are labeled. The amount of crystallized ettringite in $\mathrm{CgB} 2$ cements is higher than in $\mathrm{CgB} 0$ cements, irrespective of gypsum content (Tables 1 and 2). Ettringite formation occurs according to eqs 1 and 2 . Stratlingite is very likely formed according to reaction 4 . On the other side, katoite has a structure related to the grossular or garnet, $\mathrm{C}_{3} \mathrm{AS}_{3}$, where some or all of the silicon is omitted and the charge is balanced by replacing each of the oxygen atoms to which it was attached by hydroxyl. Moreover, $\mathrm{Al}^{3+}$ may be partly or wholly replaced by $\mathrm{Fe}^{3+}$. Consequently the katoite solid solution, also known as hydrogarnet, may be expressed as $\mathrm{C}_{3} \mathrm{~A}_{1-x} \mathrm{~F}_{x} \mathrm{~S}_{3-y / 2} \mathrm{H}_{y}^{42}$ and can be formed according to eq 5 .

By unit cell parameter inspection as explained later (Table S3 in Supporting Information), it can be stated that $y$ is 4 for all the precipitated katoites of this study and $x$ has been determined.

Figure S1 (Supporting Information) shows, as an example, DTA-TGA curves for C10B2 and C10B0 stopped-hydration pastes at 7 days. Weight losses around $100{ }^{\circ} \mathrm{C}$ are due to the loss of 32 water molecules of ettringite; ${ }^{26}$ the amount of this phase in C10B2 ( 11 wt \%) is larger than that in C10B0 $(\sim 8$ wt \%), confirming the results obtained by LXRPD.

Figure 2a,b shows the evolution of sulfate content with time for $\mathrm{C} 10 \mathrm{~B} 0$ and $\mathrm{C} 10 \mathrm{~B} 2$ pastes as representative examples. The same results for $\mathrm{C} 5 \mathrm{~B} x$ and $\mathrm{C} 15 \mathrm{~B} x$ pastes are described in Supporting Information, Figures S2 and S3, respectively. The amount of hydrated sulfate content was calculated from the quantitative data reported in Tables 1 and 2 for $\mathrm{C}_{4} \mathrm{~A}_{3} \overline{\mathrm{S}}$ and $\mathrm{C} \overline{\mathrm{S}} \mathrm{H}_{2}$. In addition, the crystallized sulfate content (squares) was calculated from the quantified ettringite. The dotted line in Figure $2 \mathrm{a}, \mathrm{b}$ represents the maximum sulfate group content that can be hydrated and/or crystallize. As mentioned before, $\mathrm{AFt}$ crystallization in B2 is higher than in B0 pastes: $~ 75 \%$ of the hydrated sulfates have crystallized for $\mathrm{C} 10 \mathrm{~B} 2$ against $~ 55 \%$ for C10B0, meaning that, in this case, $\sim 45 \%$ of hydrated sulfate groups were mainly incorporated into ACn phase(s) and/or in pore solution.

Stratlingite, as mentioned before, is one of the main hydrated phases in these cements. It is worth pointing out that, in nonactivated cements $(\mathrm{CgB0})$, the early hydration of $\beta-\mathrm{C}_{2} \mathrm{~S}$ does not occur according to reaction 3 , as for OPC, inasmuch as $\mathrm{CH}$ is not detected in the pastes. On the contrary, belite is mainly involved in the reaction with $\mathrm{AH}_{3}$ to yield stratlingite (reaction 4). Moreover, the stratlingite crystallization process is strongly affected by the amount of added gypsum; in fact, stratlingite decreases with increasing gypsum content.

The crystallization of large amounts of stratlingite by reaction 4 is confirmed by DTA measurements: Figure 3 shows the DTA curves for $\mathrm{C} 15 \mathrm{~B} 0$ at all the studied ages. The endothermic signal at $\sim 235^{\circ} \mathrm{C}$, corresponding to the dehydration of $\mathrm{AH}_{3}{ }^{6}$ is present at 3 and 7 days. After 28 and 120 days, this signal disappears and two endothermic peaks related to stratlingite 6 appear at $160-175$ and $\sim 200{ }^{\circ} \mathrm{C}$ (arrows in Figure 3), thus confirming its generation from $\mathrm{AH}_{3}$.

Figure 2c,d shows the evolution of silicate contents (hydrated and crystallized silicate) during the hydration time for $\mathrm{C} 10 \mathrm{~B} x$ as a representative example. Figures S2 and S3 (Supporting Information) show the same evolution for $\mathrm{C} 5 \mathrm{~B} x$ and $\mathrm{C} 15 \mathrm{~B} x$, respectively. On the one hand, hydrated silicate contents stand for the amount of silicon-bearing phases that have reacted with water (calculated from belite consumption, Tables 1 and 2). On the other hand, crystallized silicate contents mean the amount of silicon-containing crystalline hydrated phases that have precipitated and been quantified, that is, stratlingite and katoite from Tables 1 and 2 . The chosen stoichiometry of katoite in each cement paste will be discussed below. The dotted lines in Figure $2 \mathrm{c}, \mathrm{d}$ stand for the maximum hydrated silicate content for $\mathrm{C} 10 \mathrm{~B} x$ cement pastes. The amount of crystallized silicate is higher in nonactivated cements, where higher amounts of stratlingite were found. Thus, a higher amount of hydrated silicate remains in the amorphous phase(s) for $\mathrm{CgB} 2$, probably as $\mathrm{C}-\mathrm{S}-\mathrm{H}$ gel, according to the higher amounts of ACn determined by RQPA and G-factor approach (Tables 1 and 2).

The amount of precipitated crystalline katoite seems to depend on $\mathrm{C}_{4} \mathrm{AF}$ hydration, as significant amounts of this siliceous-hydrogarnet phase crystallizes just after the decrease of $\mathrm{C}_{4} \mathrm{AF}$ (Tables 1 and 2). This supports the opinion that katoite might contain a significant amount of iron as a substitute for aluminum and that $\mathrm{C}_{4} \mathrm{AF}$ hydration mechanism corresponds to reaction 5 rather than to reaction 2 . Refined $a$ unit cell parameters obtained in cubic katoites, for all cement pastes, were compiled (Table S3, Supporting Information). According to the equation $a=0.16 x+12.29$, obtained by assuming a linear variation of the unit cell, ${ }^{38}$ the $\mathrm{Al} / \mathrm{Fe}$ ratio in $\mathrm{C}_{3} \mathrm{~A}_{1-x} \mathrm{~F}_{x} \mathrm{SH}_{4}$ can be estimated (Table S3). The average value of the refined unit cell parameters at different hydration ages was used in the cement pastes for which the standard deviation $\left(\sigma_{n-1}\right)$ was lower than 0.009 . When $\sigma_{n-1}$ was higher, the average 

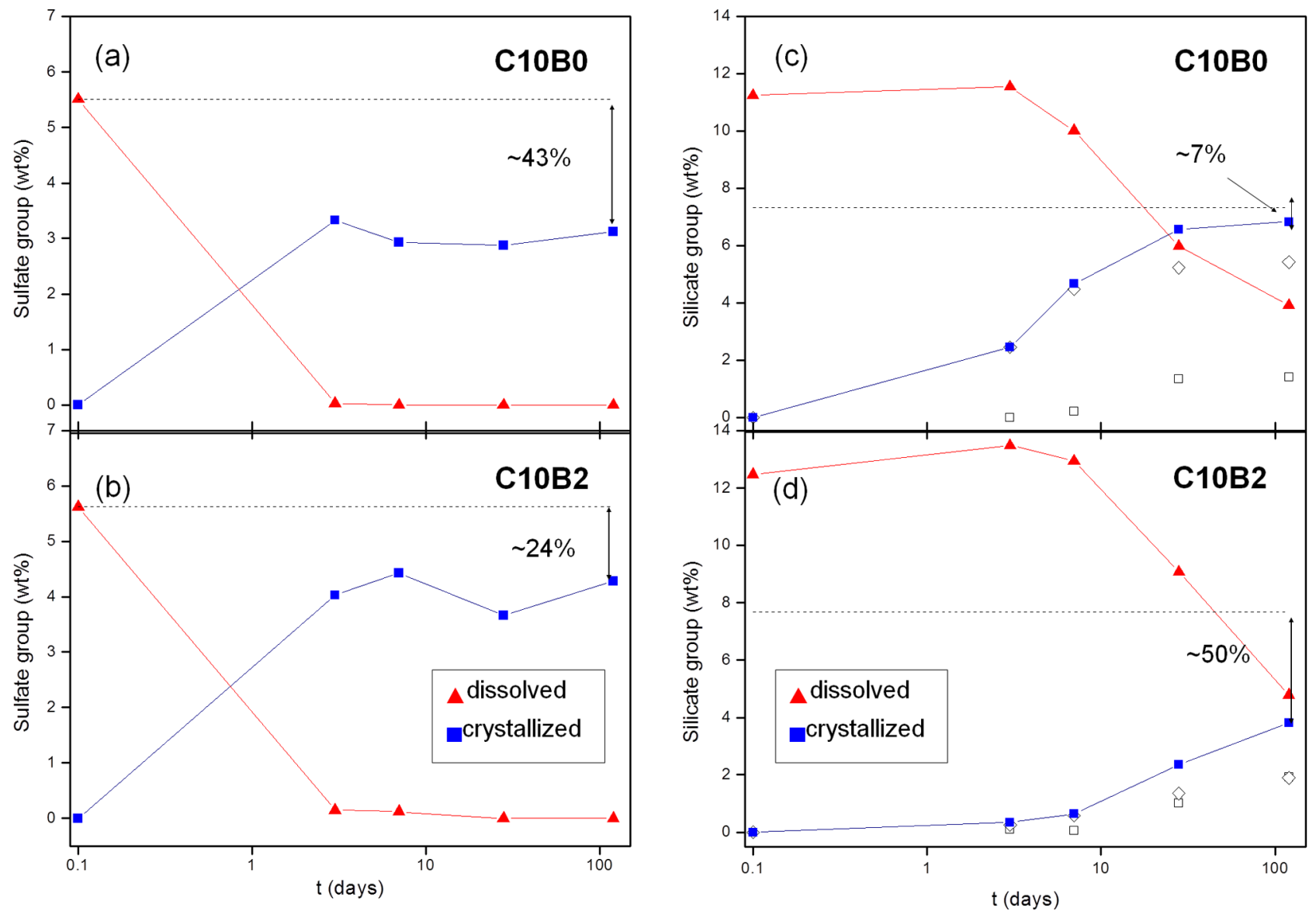

Figure 2. Hydration and crystallization rates of (a, b) sulfate groups and (c, d) silicate groups for (a, c) C10B0 and (b, d) C10B2 pastes. ( $\square, \diamond$ ) Silicate from katoite and stratlingite, respectively. Dashed lines represent the maximum values of dissolved groups.

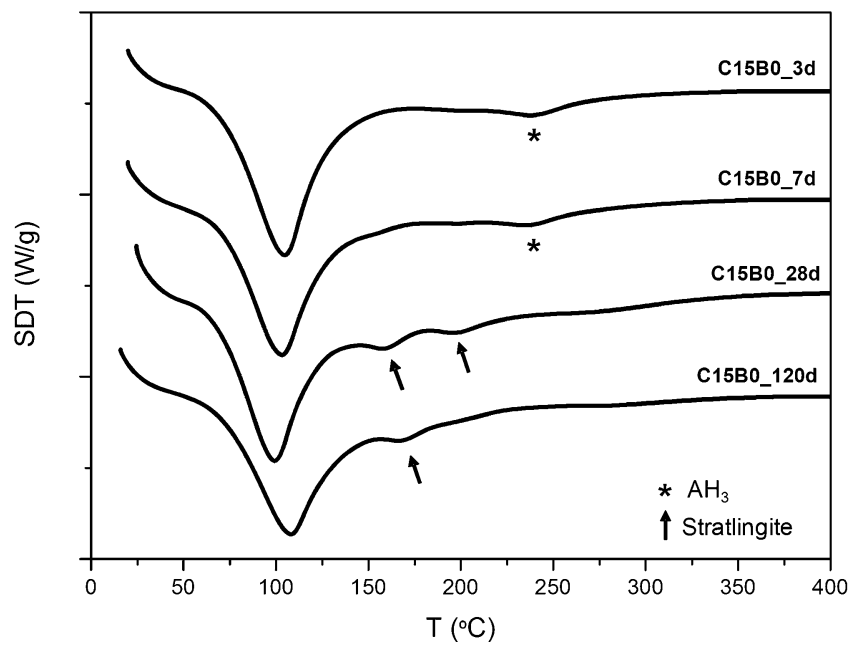

Figure 3. Differential thermal analysis for $\mathrm{C} 15 \mathrm{~B} 0$ cement pastes cured at $3,7,28$, and 120 days $(\mathrm{w} / \mathrm{c}=0.55)$.

was not calculated. Figure 4a,b (for C10B0 and C10B2, respectively) shows the hydrated and crystallized iron-bearing group contents also calculated by using the stoichiometric data given in Table S3 for katoite. Figures S4 and S5 (Supporting Information) give the same data for $\mathrm{C} 5 \mathrm{~B} x$ and $\mathrm{C} 15 \mathrm{~B} x$, respectively. It can be observed that the amount of crystalline precipitated iron-bearing group can coincide with the maximum hydrated or even can be larger, which does not have a chemical sense. This latter mismatch may arise from two facts: (i) the errors in RQPA can be close to 5-10\% for the minor phases ${ }^{23}$ and, more relevant, (ii) the stoichiometry chosen for both $\mathrm{C}_{4} \mathrm{AF}$ and katoite is inaccurate. However, in spite of this mismatch, it can be stated that all the hydrated iron crystallized as katoite; thus $\mathrm{ACn}, \mathrm{AFt}$, or $\mathrm{AFm}$ phases did not contain significant amounts of iron.

The evolution of aluminum was also studied by the same methodology. Hydrated aluminate contents were obtained from $\mathrm{C}_{4} \mathrm{~A}_{3} \overline{\mathrm{S}}$ and $\mathrm{C}_{4} \mathrm{AF}$ consumption, and crystallized aluminate amounts were calculated from the precipitated AFt, katoite, and stratlingite. Evolution of aluminate with hydration time is given in Figure 4 for $\mathrm{C} 10 \mathrm{~B} x$ and in Figures S4 and S5 (Supporting Information) for $\mathrm{C} 5 \mathrm{~B} x$ and $\mathrm{C} 15 \mathrm{~B} x$, respectively. The amount of crystallized aluminum-bearing phases was higher in $\mathrm{CgB0}$ cement pastes, matching in some cases the maximum, whereas more than $30 \%$ of the aluminate content remained in the $\mathrm{ACn}$ phase(s) for $\mathrm{CgB} 2$ cement pastes, and/or to a minor extent in pore solution.

Finally, a carbonation phenomenon took place as small amounts of crystalline calcite and/or vaterite were found after 28 and 120 days of hydration in some cement pastes (Tables 1 and 2). These results were confirmed by an increase of the weight losses from 600 to $1000{ }^{\circ} \mathrm{C}$ in TGA (Table S2, Supporting Information), confirming the accuracy of RQPA methodology.

Figure 5 illustrates the strength development of mortars prepared with $\mathrm{CgB0}$ and $\mathrm{CgB} 2$ cements, described in the Experimental Section. Figure 5 also displays similar values for 

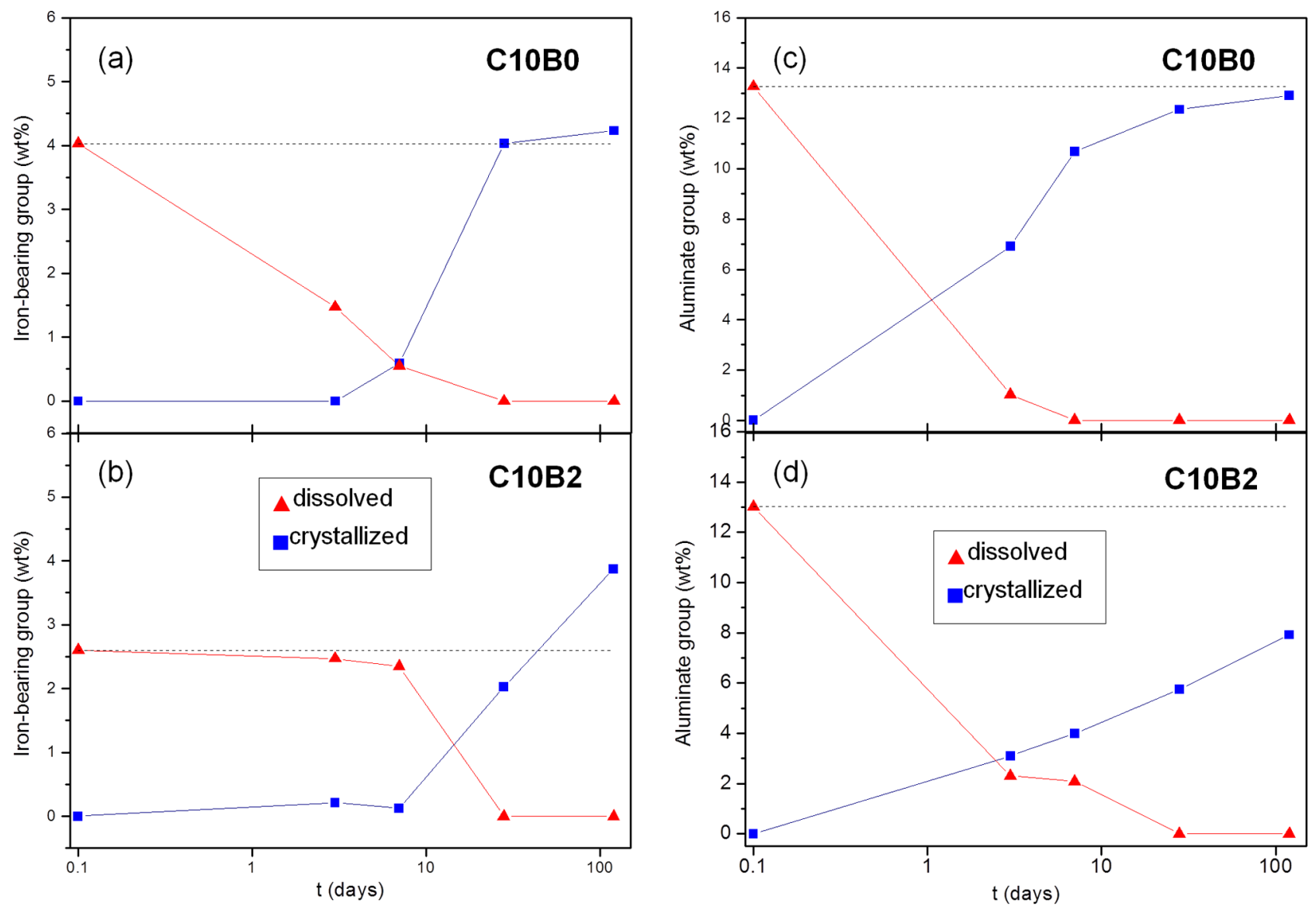

Figure 4. Hydration and crystallization rates of (a, b) iron-bearing groups and (c, d) aluminate groups for (a, c) C10B0 and (b, d) C10B2 pastes. Dashed lines represent the maximum value of dissolved groups.

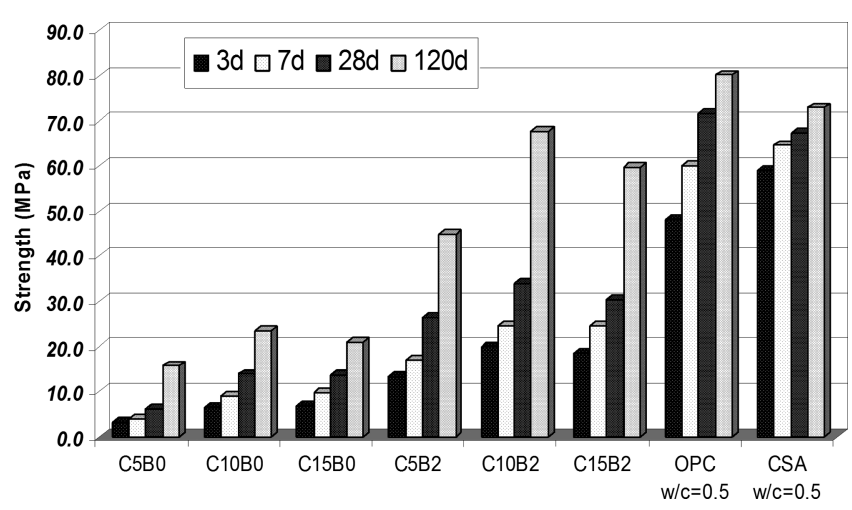

Figure 5. Compressive strength development for $\mathrm{CgB} 0$ and $\mathrm{CgB} 2$ mortars with different amounts of gypsum. Reference values for OPC and CSA mortars are also given.

reference mortars prepared from a commercial CSA with $25 \mathrm{wt}$ $\%$ gypsum $^{27}$ and an OPC (CEM-I 52.5R). The most important finding was that $\mathrm{CgB} 2$ mortars showed higher strengths than those of $\mathrm{CgB0}$ mortars at any curing time, irrespective of the gypsum content. Consequently, it can be stated that the higher hydration rate of $\beta-\mathrm{C}_{2} \mathrm{~S}$ in $\mathrm{CgB} 0$ pastes does not imply a higher mechanical strength. Thus, the hydration products mainly influence the strength development of the mortars: the higher the amount of stratlingite, the lower the compressive strength.

In addition, with the increase in gypsum content from 5 to 10 wt $\%$, the compressive strength increases. Furthermore, the addition of 15 wt $\%$ gypsum provoked a slight decrease in the mechanical strength, probably due to the slowdown of belite hydration rate. The optimum amount of gypsum in these systems seems to be quite close to $10 \mathrm{wt} \%$, as higher mechanical strengths are obtained at any curing time. At early ages the strength values obtained for $\mathrm{CgB} x$ cements are much lower than those of OPC or CSA cement. However, after 120 days of hydration, C10B2 mortars reached mechanical strengths quite close to those displayed by OPC and CSA cements. The longitudinal modifications of the mortars with hydration time were also measured and the data are summarized in Figure 6. This figure represents the percentage of length change with respect to the initial value as detailed in the Experimental Section. The expansion (or shrinkage) experienced by mortars is mainly related to the nature of pore structure, which affects the mobility of ions and the amount of space for reaction products to form. The low expansion values obtained for these mortars agree with previous studies. ${ }^{43}$ Our study has revealed the effect of gypsum content in dimensional stability of BCSA mortars. The addition of 15 wt \% gypsum caused the highest expansions for both systems due to the larger amounts of $\mathrm{AFt}$ formed, ${ }^{43}$ comparable, as expected, to commercial CSA. The expansion in $\mathrm{C} 15 \mathrm{~B} 0$ was so severe that the mortar prism appeared cracked after 3 hydration days. A photograph of the broken prism is shown in the inset of Figure 6, where a significant amount of ettringite crystals (white powder) is appreciable inside the crevice. According to Figure 6, C5B0 and $\mathrm{C} 10 \mathrm{~B} 0$ experienced very low expansion values and almost negligible dimensional changes with time, likely due to the lower amounts of $\mathrm{AFt}$ formed compared to $\mathrm{CgB} 2$ mortars (see 


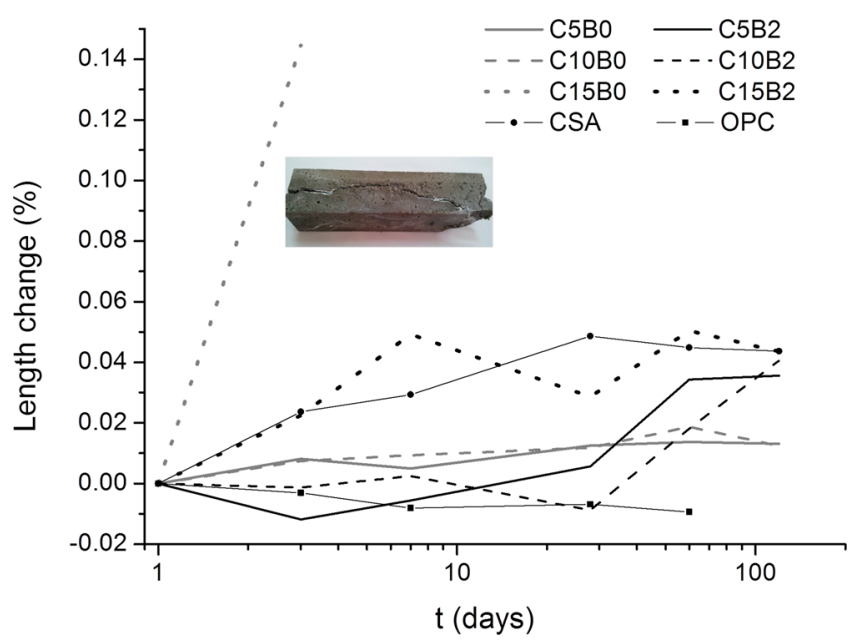

Figure 6. Length change measurements for mortars of $\mathrm{CgBO}$ and $\mathrm{CgB}$. Corresponding values for OPC and CSA mortars are also given for the sake of comparison.

Tables 1 and 2). On the other hand, C5B2 and C10B2 mortars showed a length variation roughly from $-0.01 \%$ to $0.04 \%$ within 120 days.

\section{CONCLUSIONS}

This study has unraveled the hydration behavior up to 120 hydration days of two laboratory-prepared BCSA cements: one nonactivated BCSA cement with $\beta$-belite as the main phase and one activated BCSA cement with $\alpha^{\prime}{ }_{\mathrm{H}}$-belite stabilized by the addition of borax. Rietveld quantitative phase analysis, including amorphous phases and crystalline nonquantified fraction and free water, was used to determine the degree of reaction $(\alpha)$ of main crystalline starting phases as a function of time and the amount of gypsum added. The increase of gypsum addition to BCSA cements caused a slowdown in hydration rate of belite (independently of the polymorphism) and ferrite. Meanwhile, ye'elimite reactivity pace is not strongly affected by the amount of gypsum, as after three days more than $90 \%$ was hydrated in all pastes. On the other hand, the reaction degree of dicalcium silicate at 120 hydration days was significantly affected by the amount of gypsum. $\beta-\mathrm{C}_{2} \mathrm{~S}$ reactivity, $\alpha$, was enhanced by increasing the gypsum content ( $\alpha$ rose from $65 \%$ to $75 \%$ for addition of 5 or 15 wt \% gypsum, respectively). Nevertheless, $\alpha^{\prime}{ }^{\prime}$-belite reaction degree decreased from $62 \%$ to $42 \%$ for addition of 5 or $15 \mathrm{wt} \%$ gypsum, respectively.

The activation of BCSA also affected the hydration behavior of the main phases. Ye'elimite phase in the nonactivated binder presented an orthorhombic crystal structure and reacted at a higher extent than in the activated BCSA for the same gypsum content and age of hydration. An astonishing conclusion is the higher reactivity rate with water of $\beta-\mathrm{C}_{2} \mathrm{~S}$, when compared to the $\alpha^{\prime}{ }_{\mathrm{H}}$ form, for a fixed gypsum content and time of hydration. In fact, $\beta-\mathrm{C}_{2} \mathrm{~S}$ in nonactivated BCSA with $10 \mathrm{wt} \%$ gypsum after 28 hydration days presented a reaction degree of $47 \%$, and more than $20 \mathrm{wt} \%$ stratlingite had crystallized. Meanwhile, $\alpha^{\prime}{ }_{\mathrm{H}^{-}}$ $\mathrm{C}_{2} \mathrm{~S}$ displayed $27 \%$ reaction degree in activated BCSA with less than $10 \mathrm{wt} \%$ crystalline stratlingite. In spite of this behavior, nonactivated BCSA presented lower mechanical strengths at any age than activated BCSA cement. The main conclusion of this work is that the hydration mechanism of belite determines the development of mechanical strength. Consequently, if there is availability of aluminum hydroxide, belite will react to form stratlingite and lower mechanical strengths will be developed. Moreover, the optimum amount of gypsum addition was proved to be close to $10 \mathrm{wt} \%$, as higher mechanical strengths and lower shrinkage are obtained.

\section{ASSOCIATED CONTENT}

\section{S Supporting Information}

Additional text with experimental details about laboratory X-ray powder diffraction data collection; three tables listing elemental composition of clinkers and gypsum determined by $\mathrm{X}$-ray fluorescence, thermal analysis data, and unit cell parameter and iron content of katoites; and five figures showing thermal analysis curves for selected cements and dissolution and crystallization rates of sulfate, silicate, iron-bearing, and aluminate groups for selected cements. This material is available free of charge via the Internet at http://pubs.acs.org.

\section{AUTHOR INFORMATION}

\section{Corresponding Author}

*E-mail mgd@uma.es.

\section{Notes}

The authors declare no competing financial interest.

\section{ACKNOWLEDGMENTS}

This work was supported by Spanish MINECO through MAT2010-16213 research grant, which is cofunded by FEDER. I.S. appreciates a Ramón y Cajal fellowship, RYC-2008-03523.

\section{REFERENCES}

(1) Schneider, M.; Romer, M.; Tschudin, M.; Bolio, H. Sustainable cement production-present and future. Cem. Concr. Res. 2011, 41, $642-650$.

(2) Habert, G. Environmental impact of Portland cement production. In Eco-efficient concrete; Pacheco-Torgal, F., Jalali, S., Labrincha, J., John, V. M., Eds.; Woodhead Publishing Limited: Cambridge, U.K., 2013.

(3) Gartner, E. Industrially interesting approaches to "low $\mathrm{CO}_{2}$ " cements. Cem. Concr. Res. 2004, 34, 1489-1498.

(4) Chatterjee, A. K. High belite cements-Present status and future technological options: Part I and Part II. Cem. Concr. Res. 1996, 26, 1213-1237.

(5) Wang, W.; Wang, X.; Zhu, J.; Wang, P.; Ma, C. Experimental investigation and modeling of sulfoaluminate cement preparation using desulfurization gypsum and red mud. Ind. Eng. Chem. Res. 2013, 52, 1261-1266.

(6) Aranda, M. A. G.; De la Torre, A. G. Sulfoaluminate cement. In Eco-efficient concrete; Pacheco-Torgal, F., Jalali, S., Labrincha, J., John, V. M., Eds.; Woodhead Publishing Limited: Cambridge, U.K., 2013.

(7) Pace, M. L.; Telesca, A.; Marroccoli, M.; Valenti, G. L. Use of industrial byproducts as alumina sources for the synthesis of calcium sulfoaluminate cements. Environ. Sci. Technol. 2011, 45, 6124-6128.

(8) Sharp, J. H.; Lawrence, C. D.; Yang, R. Calcium sulfoaluminate cements-low-energy cements, special cement or what? Adv. Cem. Res. 1999, 11, 3-13.

(9) Li, G. S.; Gartner, E. M. (Lafarge). High-belite sulfoaluminate clinker: fabrication process and binder preparation. World Patent Application WO 2006/018569 A2, 23 Feb 2006.

(10) Cuberos, A. J. M.; De la Torre, A. G.; Álvarez-Pinazo, G.; Martín-Sedeño, M. C.; Schollbach, K.; Pöllmann, H.; Aranda, M. A. G. Active iron-rich belite sulfoaluminate cements: Clinkering and hydration. Environ. Sci. Technol. 2010, 44, 6855-6862.

(11) Walenta, G.; Comparet, C.; Morin, V.; Gartner, E. (Lafarge). Hydraulic binder based on sulfoaluminate clinker and minerals additions. World Patent Application WO 2010/070215 A1, 24 Jun 2010. 
(12) Meller, N.; Hall, C.; Jupe, A. C.; Colston, S. L.; Jacques, S. D. M.; Barnes, P.; Phipps, J. The paste hydration of brownmillerite with and without gypsum: a time resolved synchrotron diffraction study at 30, 70, 100 and $150^{\circ}$ C. J. Mater. Chem. 2004, 14, 428-435.

(13) Möschner, G.; Lothenbach, B.; Winnefeld, F.; Ulrich, A.; Figi, R.; Kretzschmar, R. Solid solution between Al-ettringite and Feettringite $\left(\mathrm{Ca}_{6}\left[\mathrm{Al}_{1-\mathrm{x}} \mathrm{Fe}_{\mathrm{x}}(\mathrm{OH})_{6}\right]_{2}\left(\mathrm{SO}_{4}\right)_{3} \cdot 26 \mathrm{H}_{2} \mathrm{O}\right)$. Cem. Concr. Res. 2009, 39, 482-489.

(14) Dilnesa, B. Z.; Lothenbach, B.; Renaudin, G.; Wichser, A.; Wieland, E. Stability of monosulfate in the presence of iron. J. Am. Ceram. Soc. 2012, 95, 3305-3316.

(15) Jelenic, I.; Bezjak, A.; Bujan, M. Hydration of $\mathrm{B}_{2} \mathrm{O}_{3}$-stabilized $\alpha$ and $\beta$-modifications of dicalcium silicate. Cem. Concr. Res. 1978, 8, $173-180$.

(16) Gies, A.; Knofel, D. Influence of sulfur on the composition of belite-rich cement clinkers and the technological properties of the resulting cements. Cem. Concr. Res. 1987, 17, 317-328.

(17) Martín-Sedeño, M. C.; Cuberos, A. J. M.; De la Torre, A. G.; Álvarez-Pinazo, G.; Ordoñez, L. M.; Gateshki, M.; Aranda, M. A. G. Aluminium-rich belite sulfoaluminate cements: Clinkering and early age hydration. Cem. Concr. Res. 2010, 40, 359-369.

(18) Odler, I. Hydration, setting and hardening of Portland cement. In Lea's Chemistry of Cement and Concrete, 4th ed.; Hewlett, P. C., Ed.; Elsevier: Oxford, U.K., and Burlington, MA, 2003; pp 241-297.

(19) Andac, M.; Glasser, F. P. Pore solution composition of calcium sulfoaluminate cement. Adv. Cem. Res. 1999, 11, 23-26.

(20) Rinaldi, R.; Sacerdoti, M.; Passaglia, E. Straetlingite: crystal structure, chemistry, and a reexamination of its polytype vertumnite. Eur. J. Min. 1990, 2, 841-849.

(21) Wang, J. Hydration mechanism of cements based on low- $\mathrm{CO}_{2}$ clinkers containing belite, ye'elimite and calcium alumino-ferrite. Ph.D. Thesis, University of Lille, France, 2010.

(22) Martínez-Ramírez, S.; Blanco-Varela, M. T. Thermodynamically stable phases in the $\mathrm{CaO}-\mathrm{SiO}_{2}-\mathrm{Al}_{2} \mathrm{O}_{3}-\mathrm{CaSO}_{4}-\mathrm{H}_{2} \mathrm{O}$ closed system at 25 ${ }^{\circ} \mathrm{C}$. Application to cementitious systems. Mater. Construct. 2009, 59 (294), 31-39.

(23) León-Reina, L.; De la Torre, A. G.; Porras-Vázquez, J. M.; Cruz, M.; Ordonez, L. M.; Alcobe, X.; Gispert-Guirado, F.; Larrañaga-Varga, A.; Paul, M.; Fuellmann, T.; Schmidt, R.; Aranda, M. A. G. Round robin on Rietveld quantitative phase analysis of Portland cements. J. Appl. Crystallogr. 2009, 42, 906-916.

(24) Scrivener, K. L.; Fullmann, T.; Gallucci, E.; Walenta, G.; Bermejo, E. Quantitative study of Portland cement hydration by X-ray diffraction/Rietveld analysis and independent methods. Cem. Concr. Res. 2004, 34, 1541-1547.

(25) Álvarez-Pinazo, G.; Cuesta, A.; García-Maté, M.; Santacruz, I.; Losilla, E. R.; De la Torre, A. G.; León-Reina, L.; Aranda, M. A. G. RQPA ye'elimite-containing-cements. Cem. Concr. Res. 2012, 42, 960971.

(26) Odler, I.; Abdul-Maula, S. Possibilities of quantitative determination of the $\mathrm{AFt}$-(ettringite) and $\mathrm{AFm}$-(monosulphate) phases in hydrated cement pastes. Cem. Concr. Res. 1984, 14, 133-141.

(27) García-Maté, M.; De la Torre, A. G.; León-Reina, L.; Aranda, M. A. G.; Santacruz, I. Hydration studies of calcium sulfoaluminate cements blended with fly ash. Cem. Concr. Res. 2013, 54, 12-20.

(28) Jansen, D.; Goetz-Neunhoeffer, F.; Stabler, C. H.; Neubauer, J. A remastered external standard method applied to the quantification of early OPC hydration. Cem. Concr. Res. 2011, 41, 602-608.

(29) O'Connor, B. H.; Raven, M. D. Application of the Rietveld refinement procedure in assaying powdered mixtures. Powder Diffr. 1998, 3, 2-6.

(30) Cline, J. P.; Von Dreele, R. B.; Winburn, R.; Stephens, P. W.; Filliben, J. J. Addressing the amorphous content issue in quantitative phase analysis: the certification of NIST standard reference material 676a. Acta Crystallogr. A 2011, 67, 357-367.

(31) Larson, A. C.; Von Dreele, R. B. General Structure Analysis System (GSAS). Los Alamos Natl. Lab., [Rep.] LA (U. S.) 2000, 86748.
(32) Thompson, P.; Cox, D. E.; Hasting, J. B. Rietveld refinement of Debye-Scherrer synchrotron X-ray data from $\mathrm{Al}_{2} \mathrm{O}_{3}$. J. Appl. Crystallogr. 1987, 20, 79-83.

(33) Finger, L. W.; Cox, D. E.; Jephcoat, A. P. A correction for powder diffraction peak asymmetry due to diaxial divergence. J. Appl. Crystallogr. 1994, 27, 892-900.

(34) Dollase, W. A. Correction of intensities for preferred orientation in powder diffractometry: application of the March model. J. Appl. Crystallogr. 1986, 19, 267-272.

(35) Aranda, M. A. G.; De la Torre, A. G.; León-Reina, L. Rietveld quantitative phase analysis of OPC clinkers, cements and hydration products. Rev. Mineral. Geochem. 2012, 74, 169-209.

(36) Cuesta, A.; Losilla, E. R.; Aranda, M. A. G.; De la Torre, A. G. Reactive belite stabilization mechanisms by boron-bearing dopants. Cem. Concr. Res. 2012, 42, 598-606.

(37) Cuesta, A.; De la Torre, A. G.; Losilla, E. R.; Peterson, V. K.; Rejmak, P.; Ayuela, A.; Frontera, C.; Aranda, M. A. G. Structure, atomistic simulations, and phase transition of stoichiometric ye'elimite. Chem. Mater. 2013, 25, 1680-1687.

(38) Álvarez-Pinazo, G.; Cuesta, A.; García-Maté, M.; Santacruz, I.; Losilla, E. R.; Sanfélix, S. G.; Fauth, F.; Aranda, M. A. G.; De la Torre, A. G. In-situ early-age hydration study of sulfobelite cements by synchrotron powder diffraction. Cem. Concr. Res. 2013, (submitted for publication).

(39) Li, G. S.; Walenta, G.; Gartner, E. M. Formation and hydration of low- $\mathrm{CO}_{2}$ cements based on belite, calcium sulfoaluminate and calcium aluminoferrite. Proceedings of the 12th ICCC, Montreal, Canada, 2007; TH3-15.3.

(40) Cuberos, A. J. M.; De la Torre, A. G.; Martín-Sedeño, M. C.; Moreno-Real, L.; Merlini, M.; Ordónez, L. M.; Aranda, M. A. G. Phase development in conventional and active belite cement pastes by Rietveld analysis and chemical constraints. Cem. Concr. Res. 2009, 39, $833-842$.

(41) Winnefeld, F.; Lothenbach, B. Hydration of calcium sulfoaluminate cements - Experimental findings and thermodynamic modeling. Cem. Concr. Res. 2010, 40, 1239-1247.

(42) Taylor, H. F. W. Cement Chemistry, 2nd ed.; Thomas Telford Publishing: London, 1997.

(43) Chen, I. A.; Hargis, C. W.; Juenger, M. C. G. Understanding expansion in calcium sulfoaluminate-belite cements. Cem. Concr. Res. 2012, 42, 51-60. 